\title{
Role of cell block preparation in neoplastic lesions
}

\author{
Basnet $\mathrm{S}^{1}$, Talwar OP${ }^{1}$ \\ ${ }^{I}$ Department of pathology, Manipal college of medical science, Pokhara
}

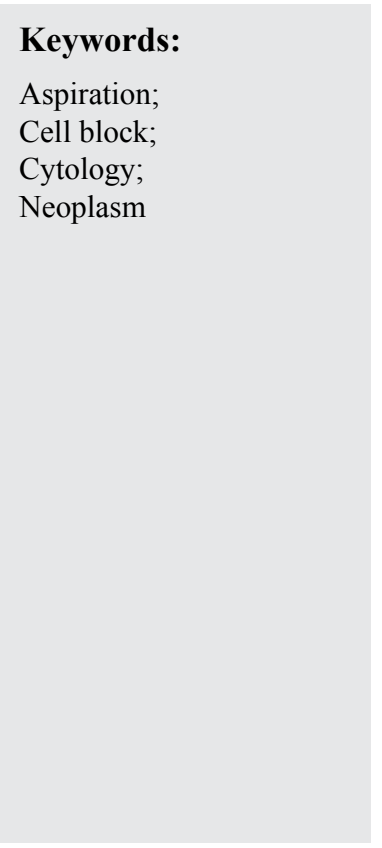

\begin{abstract}
Background: Fine needle aspiration cytology of superficial lesion or deep anatomical site is an increasingly common procedure in diagnosis of neoplastic lesions. Sometimes fine needle aspiration does not yield sufficient information for precise diagnosis and the risk of false negative or intermediate diagnosis always exists. In order to overcome these problems, cell block technique has been resorted to make the best use of available material.
\end{abstract}

Materials and Methods: This was a prospective hospital based study conducted in the department of pathology, Manipal Teaching Hospital, Pokhara, Nepal over a period of 2 years from the year 2009 October to 2011. There were total of 49 cases included in the study of which fine needle aspiration cytology smears, cell block and biopsy specimens were available.

Results: A total of 49 such cases were included in the study of which fine needle aspiration cytology smears, cell block and biopsy specimens were available. Of all the malignant cases, 12 cases were from lungs aspirate, 10 were from breast, 15 from lymph node and 12 from thyroid. With the combined use of smear and cell block, the diagnostic accuracy of the tumors approaches $100 \%$ and also significantly improves diagnostic and sub typing accuracy of malignancies. Cell blocks were found superior in diagnosing neoplasm than smears with diagnostic accuracy of $95.91 \%$ and $91.8 \%$ respectively.

Conclusion: Cell block method allows the recovery and processing of minute amounts of cellular material and facilitates the better classification of tumor when reviewed along with cytological smears. The method is simple to perform and no expertise is required to handle the specimen. Therefore the routine preparation of the cell block improves the accuracy of fine needle aspiration cytology diagnosis.

\section{INTRODUCTION}

Fine needle aspiration cytology (FNAC) of superficial lesion or deep anatomical site is an increasingly common procedure in diagnosis of neoplastic lesions. Sometimes FNA does not yield sufficient information for precise diagnosis and the risk of false negative or intermediate diagnoses always exists. ${ }^{1}$ In order to overcome these problems, cell block technique has been resorted to make the best use of the available material. ${ }^{2}$ Various methods for preparing paraffin embedded cell blocks from fine needle aspiration cytology have been

\section{Correspondence:}

Dr Sunila Basnet, $M D$

Department of pathology, Kist medical college, lalitpur, Nepal

Email:sunila77@hotmail.com reported..$^{3-9}$ These methods mainly include direct transfer of all centrifuged cellular material wrapped in lens paper $^{3-5}$ or embedding in plasma ${ }^{6,7}$ or agar ${ }^{8,9}$ and then processing as a routine histological specimen. Cell block preparation in a way mimics the histopathological sections, thus help in sub classifying various neoplastic lesions.

In this study we evaluated the diagnostic utility of cell block with respect to FNAC and its effectiveness in routine use.

\section{MATERIALS AND METHODS}

This was a prospective hospital based study conducted in the department of pathology, Manipal Teaching Hospital, 
Pokhara, Nepal over a period of 2 years from the year 2009 October to 2011. All the patients who were suspected or diagnosed as cases of malignancy in FNA smears obtained from breast, thyroid lung and lymph node were included.

FNAC was performed using 23 gauge needle attached to the $10 \mathrm{ml}$ disposable syringe under aseptic condition. Smears were made, air dried for Leishman stain or immediately alcohol fixed in $95 \%$ ethyl alcohol for Papanicolaou stain wherever needed. For cell block analysis, the remaining material in the aspirating syringe was pushed in the test tube and centrifuged at $2500 / \mathrm{rpm}$ for 10 minutes. The formed cell button was allowed to fix in $10 \%$ formalin overnight. ${ }^{10}$ Then the cell button was processed as routine biopsy specimen and stained with hematoxylin and eosin (HE) staining. The data was analyzed using $\mathrm{Z}$ test. The $\mathrm{Z}$ test was used to examine the association between different variable. A p-value of $<0.05$ was used to establish statistical significance.

\section{RESULTS}

A total of 49 such cases were included in the study of which FNAC smears, cell block and biopsy specimens were available. Of all the malignant cases, 12 cases were from lungs aspirate, 10 were from breast, 15 from lymph nodes and 12 from thyroids.

The age of the patients ranged from 15 years to 85 years with a mean of 55.8 years.

Out of 12 cases of lung cancer, in FNAC, 7/12 cases were diagnosed as adenocarcinoma of lung and 5/12 cases were diagnosed as squamous cell carcinoma (SQC) where as in cell block 6/12 cases were diagnosed as adenocarcinoma and 5 cases were diagnosed as SQC and 1/12 case was diagnosed as adenosquamous carcinoma. The comparison between FNAC findings and cell block findings are shown in Table 1.

A total of 10 cases of breast cancer were enrolled in the study. In FNAC of 3/10 cases were diagnosed as suspicious for malignancy. These 3 cases were later confirmed as invasive ductal carcinoma (IDC) in cell block preparation. $5 / 10$ cases were diagnosed as IDC and $1 / 10$ case was diagnosed as metastatic malignant melanoma to breast in both FNAC and cell block preparation. One case of metastatic adenocarcinoma in FNAC was later diagnosed as IDC in both cell block and histopathology. The cell block sections of the cases diagnosed as IDC showed tumor cells singly scattered and in occasional acinar pattern. The cells were pleomorphic with high N/C ratio, coarse chromatin and prominent nucleoli (fig.1). The FNAC smear diagnosed as metastatic malignant melanoma showed several singly scattered melanophages along with occasional clusters of atypical cell .The cell block section of same case showed several malignant melanoma cells, melanophages and areas of spindle cells arranged in fascicles (fig.2). Table 2 shows the comparison between FNAC diagnosis, cell block diagnosis and histopathology diagnosis in breast lesions.

There were a total 15 cases of cell block sections prepared from patients who were diagnosed as malignancy in FNAC. In the cell block section of all the aspirates 4/15 was positive for metastatic adenocarcinoma, another $5 / 15$ lymphnodes were positive for metastatic SQC, 1/15 was positive for metastatic melanoma and $3 / 15$ were suspicious of non-hodgkin lymphoma (NHL). Two cases of Hodgkin lymphoma in FNAC and biopsy specimen were inconclusive because of inadequate material. Comparison between FNAC findings, Cell block diagnosis and histopathology diagnosis are given in Table 3 .

In the cell block sections of Non Hodgkin lymphoma showed monotonous population of immature large lymphoid cells.

Table 1: Comparision of diagnosis by cell block with the smear of fine needle aspiration cytology in lung

\begin{tabular}{lcc}
\hline \multicolumn{1}{c}{ Diagnosis } & $\begin{array}{c}\text { FNAC } \\
\text { Diagnosis }\end{array}$ & $\begin{array}{c}\text { Cell-Block } \\
\text { Diagnosis }\end{array}$ \\
\hline Adenocarcinoma & 8 & 6 \\
SQC & 4 & 5 \\
Adenosquamous carcinoma & 0 & 1 \\
\hline Total & $\mathbf{1 2}$ & $\mathbf{1 2}$ \\
\hline
\end{tabular}

Table 2: Comparison between FNAC diagnosis, cell block diagnosis and histopathology diagnosis in breast lesion.

\begin{tabular}{lccc}
\hline \multicolumn{1}{c}{ Diagnosis } & $\begin{array}{c}\text { FNAC } \\
\text { diagnosis }\end{array}$ & $\begin{array}{c}\text { Cell-Block } \\
\text { diagnosis }\end{array}$ & $\begin{array}{c}\text { Histopathology } \\
\text { Diagnosis }\end{array}$ \\
\hline $\begin{array}{l}\text { Suspicious for } \\
\text { malignancy }\end{array}$ & 3 & 0 & 0 \\
$\begin{array}{l}\text { Adenocarcinoma } \\
\begin{array}{l}\text { Metastatic } \\
\text { adenocarcinoma }\end{array}\end{array}$ & 5 & 9 & 9 \\
$\begin{array}{l}\text { Metastatic malignant } \\
\text { melanoma }\end{array}$ & 1 & 0 & 0 \\
\hline Total & $\mathbf{1 0}$ & $\mathbf{1 0}$ & $\mathbf{1 0}$ \\
\hline
\end{tabular}

Table 3: Comparison of diagnosis by cell block, FNAC and biopsy in lymph node

\begin{tabular}{lccc}
\hline \multicolumn{1}{c}{ Diagnosis } & $\begin{array}{c}\text { FNAC } \\
\text { diagnosis }\end{array}$ & $\begin{array}{c}\text { Cell-Block } \\
\text { diagnosis }\end{array}$ & $\begin{array}{c}\text { Histopathology } \\
\text { Diagnosis }\end{array}$ \\
\hline $\begin{array}{l}\text { Metastatic squamous } \\
\text { cell carcinoma }\end{array}$ & 5 & 5 & 5 \\
$\begin{array}{l}\text { Metastatic } \\
\text { Adenocarcinoma }\end{array}$ & 4 & 4 & 4 \\
$\begin{array}{l}\text { Metastatic Malignant } \\
\text { Melanoma }\end{array}$ & 1 & 1 & 1 \\
$\begin{array}{l}\text { Hodgkin Lymphoma } \\
\text { Non- Hodgkin }\end{array}$ & 2 & 0 & 2 \\
Lymphoma & 3 & 3 & 3 \\
\hline Total & $\mathbf{1 5}$ & $\mathbf{1 3}$ & $\mathbf{1 5}$ \\
\hline
\end{tabular}


Table 4: Comparison between findings in FNAC, cell block and histopathology in thyroid lesion

\begin{tabular}{lccc}
\hline \multicolumn{1}{c}{ Diagnosis } & $\begin{array}{c}\text { FNAC } \\
\text { diagnosis }\end{array}$ & $\begin{array}{c}\text { Cell-Block } \\
\text { diagnosis }\end{array}$ & Diagnosis \\
\hline Papillary Carcinoma & 8 & 8 & 8 \\
\hline Follicular neoplasm & 2 & 2 & NA \\
\hline Follicular adenoma & NA & NA & 1 \\
\hline Follicular carcinoma & NA & NA & 1 \\
Anaplastic Carcinoma & 2 & 2 & 2 \\
\hline Total & $\mathbf{1 2}$ & $\mathbf{1 2}$ & $\mathbf{1 2}$ \\
\hline
\end{tabular}

Table No 5: Comparison study between Cell Block and FNAC

\begin{tabular}{lcccc}
\hline \multicolumn{1}{c}{ SITES $(\mathbf{n})$} & Cell Block & FNAC & Z-Value & P value \\
\hline Lung $(12$ cases) & $12(100 \%)$ & $10(83.3 \%)$ & 1.47 & $>0.05$ \\
Breast $(10$ cases $)$ & $10(100 \%)$ & $8(80 \%)$ & 1.49 & $>0.05$ \\
$\begin{array}{l}\text { Lymph Node } \\
(15 \text { cases })\end{array}$ & $13(86.67 \%)$ & $15(100 \%)$ & 1.47 & $>0.05$ \\
$\begin{array}{l}\text { Thyroid } \\
(12 \text { cases })\end{array}$ & $12(100 \%)$ & $12(100 \%)$ & NA & NA \\
\hline TOTAL $(49$ cases $)$ & $\mathbf{4 7 ( 9 5 . 9 1 \% )}$ & $\mathbf{4 5 ( 9 1 . 8 \% )}$ & $\mathbf{1 . 4 7}$ & $>\mathbf{0 . 0 5}$ \\
\hline
\end{tabular}

To make a diagnosis of NHL and to subclassify it in the cell block alone was not possible so diagnosis of suspicious for NHL was made and which later was confirmed by the histopathology as NHL.

There were a total of 12 cases of cell blocks prepared from suspected neoplastic thyroid lesions. 8/12 cases were diagnosed as papillary carcinoma, 2/11 cases were anaplastic carcinoma and 2/11 was diagnosed as follicular neoplasm. One case of follicular neoplasm turned out to be follicular adenoma where as other one follicular carcinoma in histopathology diagnosis. The cell block section findings of all the cases corroborated with the findings of FNAC diagnosis. The findings of FNAC, cell block and biopsy in thyroid lesions are shown in Table 4.

The cell block findings of the case diagnosed as papillary carcinoma showed fragments of tumor cells arranged in papillaroid pattern with distinct nuclear features. The malignant cells showed moderate amount of pleomorphism, high N/C ratio, anisonucleosis, moderate amount of cytoplasm and nuclear overlapping. The cells showed Orphan-Annie eye appearance with nuclear pseudoinclusion and nuclear grooving. (fig. 3).

In the present studies of breast, cell blocks were more specific with high diagnostic accuracy of $10(100 \%)$ and smears of $8(80 \%)$. Cell block revealed a better diagnostic accuracy than the smear.

In our study of lymphnode, the diagnostic accuracy of the cell block was $13(86.67 \%)$ and FNAC was $15(100 \%)$. In this case the diagnostic accuracy was higher in smear as due to the inconclusive diagnosis of lymphoma as to diagnose lymphoma and subclassify it in the cell block was impossible.

In our present study of thyroid, cell block diagnostic accuracy was $12(100 \%)$ and FNAC also had the similar accuracy rate of $12(100 \%)$. With the combined use of smear and cell block, the diagnostic accuracy of the tumors approaches $100 \%$ and also significantly improves diagnostic and sub typing accuracy of malignancies.

\section{DISCUSSION}

FNAC is a simple, safe and reliable, although diagnostic failure rate can be as high as $45 \%$ in FNAC. ${ }^{11}$ An inconclusive diagnosis on FNAC may be due to poor spreading, air drying artifact and presence of thick tissue fragments despite aspiration of adequate material. ${ }^{12-14}$ Different methods of cell block preparation have been reported. ${ }^{15,16}$

Musso $\mathrm{C}$ et al has described an easy one step method of cell block preparation after fine needle aspiration. The results demonstrated that the amount and quality of material obtained in the cotton wool tip is similar to that in the traditional cell block obtained from the pellet after centrifugation of aspirated fluid..$^{17}$

In our study we used $10 \%$ buffered formalin as a fixative for the cell block. Wide range of histologic fixatives have been used for cell blocks, primarily buffered formalin, neutral buffered formaldehyde solution, Bouin's solution, picric acid fixative, carnoy fixative and ethanol. , $^{1,318}$

Brown et al, ${ }^{4}$ studied 84 FNAs and revealed 55 malignancies with cytology alone but further 9 malignancies were diagnosed with aid of cell block.

There were total 12 cases of CT-guided lung aspirates of patients ranging from 55-85 years of age. Among the 12 cases included in our study, the smears and cell blocks finding were corroboratory in 10 cases $(83 \%)$ and varied in 2 cases (13\%) which corroborated with other study. ${ }^{5}$ Leung and Bedard et al found that all cases with adequate material could be diagnosed on a cell block preparation. ${ }^{16}$

In our comparison study of FNAC and cell block of lung aspirates, 2 cases showed improvement in diagnosis after the cell block was examined. One case that was diagnosed as adenocarcinoma on the smear, the cell block diagnosis was adenosquamous carcinoma. Another one case that was diagnosed as adenocarcinoma on the smear was diagnosed as SQC on the cell block.

In the present study, the diagnostic accuracy and specificity were high in cell block in comparison to the smear ranging from $83 \%$ in the smear and $100 \%$ in the cell block with Zvalue of 1.47 and $\mathrm{P}$-value $>0.05$. In this study, simultaneous 
use of cell block technique and smear examination increased the diagnostic accuracy but was statistically insignificant only due to the small sample size of the study.

The aspirated material can be processed not only for cytology but also for cell block and when use of smears and cell block is combined, diagnostic accuracy can be increased to around $90 \% .^{19}$

One of the benefits of combining cell blocks with smears is the ability to see the histologic correlates of cytologic findings. Some cytologic criteria cannot be translated into histologic criteria so complementary nature of cell blocks and smears would help avoid the pitfalls of using either cytology or histology alone. ${ }^{20}$

FNA of breast carcinoma provides highly cellular material that is representative of the tumor. We studied a total of 10 cases of carcinoma breast. In our study, FNAC of 3 cases $(30 \%)$ was diagnosed as suspicious for malignancy, 5 cases $(50 \%)$ were diagnosed as invasive ductal carcinoma, and 1 case (10\%) was of metastatic malignant melanoma. Three cases diagnosed as suspicious for malignancy in the smears, the cell block showed infiltrating ductal carcinoma.

In our study smear along with the cell blocks were diagnostic in $70 \%$ of the cases and cell block alone. In a study done by Arisio et al reported that the cell blocks improve sensitivity of breast FNAs and strongly reduce false-negative results. ${ }^{21}$

In the present study, out of 10 cases of breast lesions, cell blocks were more specific with high diagnostic accuracy of $10(100 \%)$ and $8(80 \%)$ in the smears.

We studied a total of 15 cases of patients who presented with enlarged cervical, axillary and inguinal lymphnodes. Among these 15 cases, 5 cases (33\%) were of metastatic SQC, 4 cases $(27 \%)$ of metastatic adenocarcinoma, and 5 cases $(33 \%)$ of lymphoma and 1 case $(7 \%)$ of metastatic malignant melanoma.

In present study, cases which were cytologically diagnosed as Hodgkin's lymphoma, cell blocks were non contributory due to inadequate material and hence histopathology subsequently confirmed the diagnosis.

In our study there were a total of 12 cases of cell blocks prepared from patients with suspected neoplastic lesions of thyroid. Out of which 8 cases $(67 \%)$ were papillary carcinoma, $2(16 \%)$ cases of anaplastic carcinoma and 2 (17\%) case of follicular neoplasm.

Cases which were diagnosed as papillary carcinoma on FNAC smears were also diagnosed as same on cell block. In our study of thyroid, the diagnostic accuracy of the cell blocks and smears both were $12(100 \%)$. In our study we had 2 cases $(16 \%)$ of follicular neoplasm. One case had

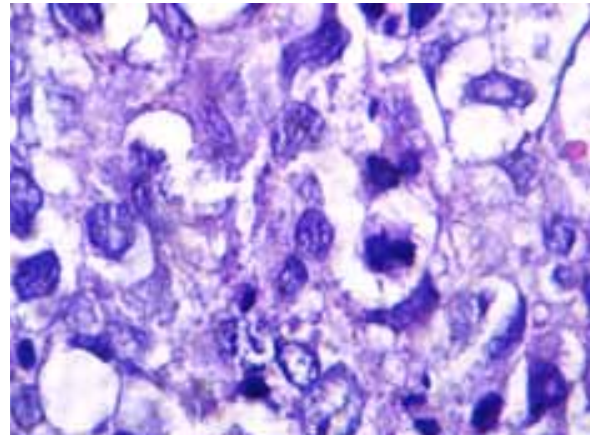

Figure 1: Cell block preparation of breast aspirate showing neoplastic cells with pleomorphism, high nucleo-cytoplasmic ratio and hyperchromatic nuclei, Invasive ductal carcinoma. (HE stain, X400)

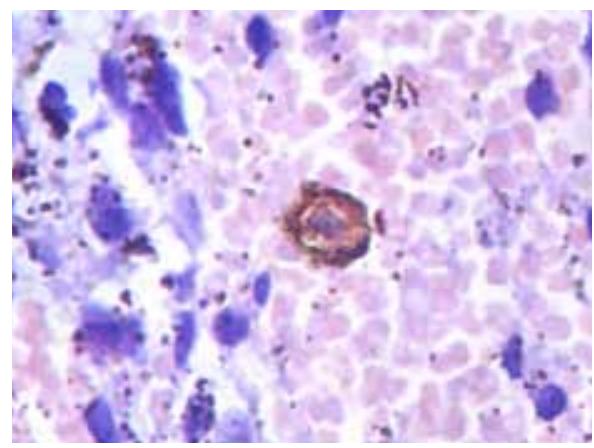

Figure 2: Cell block preparation of breast aspirate showing tumor cells with intracytoplasmic melanin pigment, Metastatic melanoma to breast (HE stain, X400).

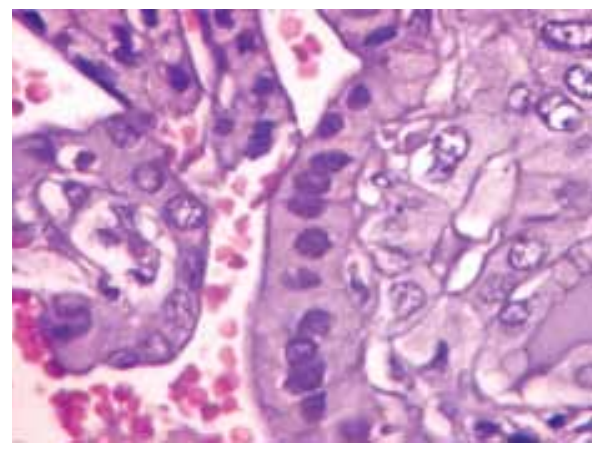

Figure 3: Cell block preparation of thyroid aspirate showing papillary fragments with optically clear tumor cells, Papillary carcinoma thyroid (HE stain, X400).

histological correlation which was diagnosed as follicular carcinoma.

In the present study, of the total 49 cases of FNAC confirmed neoplastic lesions, 47(95.91\%) cases were found to be positive by cell block method. The present study thus has an accuracy of $95.91 \%$.

In our study, the cell blocks were found superior in diagnosing neoplasm than cell block with diagnostic accuracy of $95.91 \%$ and $91.8 \%$ respectively. But the present study, in relation to the specificity and sensitivity of the cell 
block test, it had limitations due to the small sample size.

The cell block technique has added advantage that multiple sections of the same material can be obtained for special stains and immunohistochemistry. ${ }^{22}$ Apart from these, morphological details can also be obtained with cell block method, which include preservation of the architectural pattern like cell ball and papillae and three dimensional clusters, excellent nuclear and cytoplasmic details, and individual cell characteristics. On the other hand, fragments of tissue can easily be interpreted in a biopsy-like fashion. ${ }^{22}$

Cell blocks are not routinely prepared in addition to the smears. The tissue architecture can be appreciated in the cell blocks and additional cell block analysis can decrease the number of needle passes by increasing diagnostic accuracy. However if cellblock analysis is not possible for all aspirations, the technique should be used selectively in cases that are difficult to diagnose in smears.

\section{CONCLUSION}

Cell block method allows the recovery and processing of minute amounts of cellular material and facilitates the better classification of tumor when reviewed along with cytological smears. The method is simple to perform and no expertise is required to handle the specimen. Therefore the routine preparation of the cell block improves the accuracy of FNAC diagnosis.

\section{REFERENCES}

1. KuIkarni MB, Prabhudesai NM, Desai SB, Borges AM. Scrape cell block technique for fine needle aspiration cytology smears. Cytopathology. 2000;11:179-84.

2. Esposti PL, Franzen S, Zajicek J. The aspiration biopsy smear. Diagnostic cytology and its histopathological bases. Koss 2nd ed, Philadelphia and Toronto: JB Lippincott, 1968.pp565-96.

3. Zito FA, Gadaleta CD, Salvatore CL et al. A modified cell blocks technique for fine needle aspiration cytology. Acta Cytol 1995;39:939.

4. Brown KT, Fulbright RK, Avitabile AM, Bashist B. Cytologic analysis in FNA biopsy-Smears v/s cell blocks. Am J Roentgenol 1993;161:629-31
5. Wojcik EM, Selvaggi SM. Comparison of smears and cell blocks in the fine needle aspiration diagnosis. Acta Cytol 1991;35:773-6.

6. Karnanuchow PN, Bouin RE. Cells block technique for fine needle aspiration biopsy. J Clin Pathol 1992;35:688.

7. Burt AD, Smillie D, Cowan MD, Adams FG. Fine needle aspiration cytology - experience with a cell block technique. J Clin Pathol 1986;39:114-5.

8. Kung IT, Yuen RW. Fine needle aspiration of the thyroid. Distinction between colloid nodule and follicular neoplasm using cell blocks \& 21 gauze needles. Acta Cyto 1989;33:53-60.

9. Kung IT, Chan SK, Lo ES. Application of the immunoperoxidase technique to cell blocks preparations from the fine needle aspirates. Acta Cytol 1990;34:297-303.

10. Leopold G. Koss. J.B. Diagnostic cytology and its histopathologic basis. 4 ed; Lippincott: philadelphia:1979.1590pp.

11. Lee R, Foster RS, Papillo JL. Fine needle aspiration of the breast: importance of aspirator. Acta cytol 1987;31:281-4.

12. Sanchez N, Selvaghi SM. Utility of Cell Blocks in the diagnosis of thyroid Aspirates: Diagn. Cytopathol 2006;34:89-92.

13. Svante R Orell. Manual and atlas of fine needle aspiration cytology(FNAC).Churchill Livingstone Newyork.1992.96pp

14. Chen PK. Artifacts of cytology cell block in fine needle aspiration biopsy of thyroid. Diagn Cytopathol 2004;31:362-3.

15. Nathan NA, Narajan E, Smith MM, Horn MJ. Cell block cytology: Improved preparation and its efficacy in diagnostic cytology. Am J Clin Pathol 2000;114:599-606.

16. Leung SW, Bedard YC. Immunocytochemical staining on ThinPrep processed smears. Mod Pathol 1996;9:304-6.

17. Musso C, Silva-Santosh MC, Pereria FE .Cotton block method, one step method of cell blocks preparation after fine needle aspiration. Acta Cytol 2005;49:22-6.

18. Domagala WM, Markiewski M, Tuziak T, Kram A, Weber K, Osborn M. Immunocytochemistry on fine needle aspirates in paraffin miniblocks. Acta Cytol 1990;34:291-6.

19. Tsai YY, Lu SN, Changchien CS et al. Combined cytologic and histologic diagnosis of liver tumors via one-shot aspiration. Hepatogastroenterology 2002;49:644-7.

20. Baloch ZW, Tam D, Langer J, Mandel S, LiVolsi LA, Gupta PK. Ultrasound-guided fine-needle aspiration biopsy of the thyroid: role of on-site assessment and multiple cytologic preparations. Diagn Cytopathol 2000;23:425-9.

21. Arisio R, Cuccorese C, Fessia L. Role of fine needle aspiration biopsy in breast lesion:Analysis of a series of 4110 cases. Diagn cytopathol 1998;18:462-7.

22. Thapar M, Mishra RK, Goyal V. Critical analysis of cell block versus smear examination in effusions. J Cytol 2009;26:60-4. 